\title{
AKUNTABILITAS PENGELOLAAN ANGGARAN PENDAPATAN DAN BELANJA DESA (APBDES) 2017 DI DESA POTO
}

\author{
Cendra Wawansyah
}

Email: wawancendrawawansyah@gmail.com

\begin{abstract}
ABSTRAK
Tujuan dari penelitian ini untuk mengetahui bagaimana akuntabilitas pengelolaan pendapatan dan belanja di desa Poto yang meliputi kegiatan perencanaan, pelaksanaan, penatausaaan, penatausahaan dan pertanggungjawaban yang digunakan metode kualitatif dengan pendekatan deskritif kualitatif. Hasil penelitian ini menujukan bahwa Akuntabilitas di Desa Poto Kec. Moyo Hilir Kab. Sumbawa secara umum sudah baik. Hanya saja ada beberapa tahap yang tidak sesuai dengan peraturan menteri dalam negeri No.2014. untuk tahap perencanaan Sekretaris Desa menyampaikan rancangan Peraturan Desa tenang APBDes berdasarkan RKPDes kepada Kepala Desa. Kemudian dibahas dan disepakati Kepala Desa dan Badan Permusyawaratan Desa. Hal ini telah sesuai dengan Permendagri No.113 . untuk tahap pelaksanaan semua penerimaan dan pengeluaran dalam rangka pelaksanaan kewenangan desa dilaksanakan melalui rekening kas desa dan Pemerintah desa dilarang melakukan pungutan sebagai penerimaan desa Hal ini telah sesuai dengan Permendagri No.113 dan tahap pertanggungjawaban Hasil yang diperoleh dari lapangan pertanggungjawaban keuangan Desa Poto, dimana dalam hal ini terjadi sedikit ketidaaksesuaian yaitu pertanggungjawaban belum diinformasikan secara maksimal kepada seluruh masyarakat Desa Poto, berdasarkan Permendagri No.113 Tahun 2014 pasal 40 yang mengatur bahwa laporan pertanggungjawaban realisasi pelaksanaan APBDes diinformasikan kepada masyarakat secara tertulis dan dengan media yang mudah diakses oleh masyarakat karena penggunaan Website belum optimal dan belum bisa di akses.

Kata Kunci: Akuntabilitas, Pengelolaan, dan APBDes.
\end{abstract}

\section{ABSTRACT}

The purpose of this study is to find out how the accountability of revenue and expenditure management in Poto village includes planning, implementation, management, administration and accountability activities which are used by qualitative methods with qualitative descriptive approaches. The results of this study suggest that Accountability in the village of Poto Kec. Moyo Hilir of Sumbawa Besar District in general is good. It's just that there are several stages that are not in accordance with the regulations of the Minister 
of Home Affairs No.2014. for the planning phase the Village Secretary delivered a draft Village Regulation calm on the APBDes based on the RKPDes to the Village Head. Then it was discussed and agreed upon by the Village Head and the Village Consultative Body. This was in accordance with Permendagri No.113. for the implementation stage all revenues and expenditures in the context of implementing village authority are carried out through village cash accounts and village governments are prohibited from leviing as village revenue. This is in accordance with Permendagri No.113 and the stage of accountability Results obtained from the Poto Village financial accountability field, where in this case there is a slight lack of conformity, namely accountability has not been fully informed to the entire Poto Village community, based on Article 40 of Permendagri No. 113 of 2014 which stipulates that the accountability report for the realization of the APBDes is informed in writing and with media that is easily accessed by the community because of its use The website is not optimal and cannot be accessed.

Keyword: Accountability, management, and APBDes.

\section{PENDAHULUAN}

Desa adalah pelopor sistem demokrasi yang otonomi dan berdaulat penuh serta memiliki norma sosial masing-masing. Desa sebagai kawasan otonom diberikan hak-hak istimewa, seperti pengelolaan anggaran desa (Iqsan, 2016). Menurut Virgie, dkk (2013: 97) pengelolaan keuangan desa diturunkan dalam bentuk kebijakan desa berupa Anggaran Pendapatan dan Belanja desa (APBDes).

APBDes merupakan penjabaran kebutuhan daerah dalam membangun desa sebagaimana diatur dalam Permendagri Nomor 37 Tahun 2007 tentang Pedoman Pengelolaan Keuangan Desa.Untuk dapat menyusun Rencana Anggaran Pendapatan Belanja Daerah (RAPBD) berdasarkan anggaran berbasis kinerja (ABK) diperlukan kinerja sesuai dengan prinsip-prinsip good governance. Kinerja anggaran merupakan sistem penganggaran yang berorientasi pada output organisasi dan berkaitan dengan visi, misi, dan rencana organisasi. Kinerja Instansi Pemerintah dalam penyusunan anggaran digunakan untuk mengetahui tingkat pencapaian dalam penganggaran (Wandari et al, 2015).

Sesuai dengan Permendagri No. 37 tahun 2007, Anggaran Pendapatan dan Belanja Desa (APBDesa) adalah rencana keuangan tahunan pemerintahan desa yang dibahas dan disetujui bersama oleh Pemerintah Desa dan Badan Permusyawaratan Desa (BPD), dan ditetapkan dengan peraturan desa. Desa yang merupakan daerah otonom terendah, otomatis akan menjadi objek dari berlangsungnya sistem desentralisasi fiskal yang diperoleh 
dari pemerintah pusat dan pemerintah daerah. Pengelolaan keuangan desa diturunkan dalam bentuk kebijaksanaan desa berupa Anggaran Pendapatan dan Belanja Desa (APBDesa). APBDesa adalah peraturan desa yang memuat sumber-sumber penerimaan dan alokasi pengeluaran desa dalam kurun waktu satu tahun.

Penyusunan APBDes dan adanya Dana Desa merupakan bentuk desentralisasi untuk mendorong good governance. Good governance (Solekhan, 2012:15) merupakan penyelenggaraan pemerintahan negara yang solid dan bertanggung- jawab, serta efisien dan efektif dengan menjaga keseimbangan sinergitas konstruktif antara domain negara, sektor swasta, dan masyarakat. Tidak mudah menerapkan prinsip-prinsip good governance pada pemerintahan tingkat pusat maupun pemerintahan tingkat daerah bahkan pemerintahan desa.

Penelitian ini memiliki alasan tersendiri dalam memilih program APBDes. Ketertarikan ini dikarenakan APBDes memiliki implikasi yang besar dalam pembangunan sebuah desa. Faktor lain yang mendorong penulis dalam melakukan penelitian mengenai akuntabilitas pengelolaan APBDes di desa poto karena penelitijuga ingin menjelaskan pengelolaan APBDes di Desa Poto. Peneliti lebih memilih meneliti mengenai program ini karena jika dana dikekola secara jujur dan baik, maka hasil pembangunan juga terlihat dengan jelas begitupun sebaliknya. Sehingga rumusan masalah yang muncul dalam penelitian ini adalah bagaimanakah akuntabilitas pengelolaan pendapatan dan belanja di desa Poto?

\section{METODE PENELITIAN}

Pada penelitian ini penulis melakukan penelitian di Desa Poto kec. Moyo Hilir kab. Sumbawa. Penelitian dilakukan pada bulan Agustus sampai bulan September 2018. Jenis penelitian yang digunakan adalah penelitian kualitatif, menurut Strauss dan Corbin (1997:11-13) adalah jenis penelitian yang menghasilkan penemuan-penemuan yang tidak dapat dicapai (diperoleh) dengan menggunakan prosedur-prosedur statistik atau cara-cara lain dari kuantifika (pengukuran).

Dalam penelitian ini pemilihan informan menggunakan metode purposive sampling (sampel bertujuan). Menurut Sugiyono (2008:218-219) purposive sampling yaitu, informan-informan yang peneliti tentukan, merupakan orang-orang yang menurut peneliti memiliki informasi yang dibutuhkan dalam penelitian ini, karena mereka (informan) dalam keseharianya senantiasa berurusan dengan permasalahan yang sedang peneliti teliti. 
Teknik pengumpulan data yang digunakan dalam penelitian ini adalah sebagai berikut :

1. Observasi, metode pengumpulan data dengan cara melakukan pengamatan lansung pada objek yang diteliti.

2. Wawancara, yaitu metode untuk mendapatkan data dengan cara melakukan tanya jawab secara lansung dengan pihakpihak yang bersangkutan untuk mendapatkan data dan keterangan yang menunjang analisis dalam penelitian.

3. Study literatur, metode pengumpulan data dengan cara melakukan peninjauan pustaka dari berbagai literatur karya ilmiah, majalah dan buku-buku yang menyangkut teori-teori yang relevan dengan masalah yang diteliti.

4. Dokumentasi, dilakukan dengan cara mengumpulkan data melalui dokumen baik yang berbentuk tulisan, gambar atau karya-karya manumental seseorang, dan menyalin, melihat, serta mengevaluasi laporan dan dokumen-dokumen yang terkait dengan objek penelitian.

Untuk menganalisis data penelitian ini, penganalisian data tersebut akan dilakukan dengan metode deskriptif kualitatif, hanya menguraikan hasil dari wawancara yang dilakukan saat dilapangan. Berikut ini adalah Alur analisis data yaitu:

1. Pengumpulan Data

Pada tahapan ini peneliti melakukan pengumpulan data, misalnya melalui wawancara, observasi lapangan, Landasan Teori .Pada tahap ini menggunakan alat-alat yang perlu, seperti tape recorder, kamera dan lain-lain. Disini peneliti harus berhati-hati dan apa adanya.

2. Reduksi Data

Dalam penelitian ini peneliti mereduksi dan memilah data hasil observasi, wawancara, maupun dokumentasi. Karena data yang diperoleh dari lapangan masih kompleks dan bersifat mentah. Maka peneliti hanya akan memilih data yang benar-benar relevan berkaitan dengan akuntabilitasAPBDesa Poto.

3. Penyajian Data

Penyajian data merupakan kegiatan ketika sekumpulan informasi disusun, sehingga memberi kemungkinan akan adanya penarikan kesimpulan

4. Penarikan Kesimpulan

Penarikan kesimpulan adalah hasil analisis yang dapat digunakan untuk mengambil tindakan.

\section{PEMBAHASAN}

Berikut ini adalah hasil wawancara (pertanyaan terlampir) dengan tim pengelola keuangan Desa poto yang terdiri dari Kepala Desa, Sekertaris Desa dan Bendahara, serta wawancara dengan 
Badan Permusyawaratan Desa (BPD), Lembaga Pemberdayaan Masyarakat Desa (LPM), untuk mengetahui akuntabilitas Anggaran Pendapatan dan Belanja Desa (APBDes):

1. Dalam Pengelolaan Anggaran Pendapatan dan Belanja Desa (APBDes)

Pengelolaan keuangan desa dilaksanakan oleh tim pengelola keuangan. Tim pengelolaan tersebut antara lain Kepala Desa selaku pemegang kekuasaan pengelolaan keuangan desa dan mewakili Pemerintah Desa dalam kepemilikan kekayaan desa yang dipisahkan. Selanjutnya Kepala Desa dibantu oleh (PTKD). Pelaksanaan Teknis Keuangan Desa (PTKD) merupakan Sekretaris Desa, Kepala Seksi dan Bendahara Desa. Sekretaris Desa bertugas untuk meyusun semua bukti tertulis atas pengelolaan keuangan desa.

Kepala Seksi bertugas sebagai pelaksanaan kegiatan sesuai bidangnya. Sedangkan Bendahara Desa mempunyai tugas menerima, menyimpan, menyetorkan, membayar, menatausahakan, dan mempertanggung jawabkan penerimaan pendapatan desa dan pengeluaran pendapatan desa dalam rangka pelaksanaan APBDes. Secara keseluruhan Pengelolaan APBDes Desa Poto sudah sesuai dengan asas-asas atau aturan yang berlaku yaitu sesuai dengan Peraturan Menteri Dalam Negeri Nomor 113 Tahun 2014 Tentang Pengelolaan Keuangan Desa. Asas tersebut adalah transparansi, akuntabel, pertanggung jawabkan dan adanya partisipasif masyarakat. Pengelolaan keuangan desa dikelola dalam masa satu tahun anggaran yakni tanggal 1 Januari sampai dengan 31 Desember. Sedangkan penyampaian Laporan realisasi Pelaksanaan APBDes oleh kepala desa dilakukan setiap akhir periode pelaksanaan anggaran kepada Bupati melalui Camat.

2. Pelaksanaan Program Kerja

Pada pelaksanaan satu periode Anggaran Pendapatan dan Belanja Desa (APBDes), Pemerintah Desa telah menetapkan beberapa rencana baik dari segi pembangunan maupun pemberdayaan masyarakat. Misalnya pada tahun 2017 Pemerintah Desa melaksanakan program pembangunan rehabilitasi jalan desa yang berlokasi di orong rea atau lokasi ponn, saluran irigasi desa yang berlokasi di kelompok bekat loka, balai desa yang berlokasi di dusun tengke dan samri dan bronjong desa yang berlokasi di dusun bekat.

3. Akuntabilitas Pemerintah Desa poto

Bentuk Akuntabilitas dan transparansi Pemerintah Desa dalam mempertanggungjawabkan laporan pengelolaan APBDes dengan cara memberikan laporan pertangggungjawaban kepada masyarakat yaitu dengan menempelkan laporan pengelolaan 
APBDes dipapan pengumuman pembangunan yang telah disedikan di Balai Desa, selain itu Pemerintah Desa juga menyampaikan Laporan pertanggungjawaban realisasi pengelolaan APBDes kepada Badan Permusyawaratan Desa (BPD), Lembaga Permberdayaan Masyarakat (LPM) pada saat musyawarah penyusunan dan pelaporan APBDes. Dalam melakukan Pengelolaan Keuangan APBDes tentunya ada pengawasan. Semua Pemerintah Desa telah diawasi oleh tim Inspektorat, pengelolaan keuangan APBDes diawasi oleh Intern Desa (Badan Permusyawaratan Desa dan masyarakat), tim ferivikasi dari Kecamatan, dan Bapenas.

Kepala Desa menyampaikan Laporan Semesteran Realisasi Pelaksanaan Anggaran Pendapatan dan Belanja Desa (APBDes) semester satu paling lambat akhir bulan Juli tahun berjalan. Disampaikan kepada Bupati atau Walikota melalui Camat. Sedangkan Laporan Pertanggungjawaban Realisasi Pelaksanaan Anggaran Pendapatan dan Belanja Desa (APBDes) setiap akhir tahun anggaran akhir bulan Januri bulan berikutnya. Laporan pertanggungjawaban realisasi pelaksanaan APBDes terdiri dari pendapatan, belanja, dan pembiayaan. Selain itu dalam melaporkan pertanggungjawaban realisasi pelaksanaan APBDes juga harus menyertakan lampiran buku pembantu kas kegiatan, rencana anggaran biaya, SPP kegiatan, SPM (Surat Perintah Membayar), surat pernyataan pertanggungjawaban, surat keterangan wajib pajak, buku kas umum, buku kas bank dan buku kegiatan. Laporan pertanggungjawaban realiasasi pelaksanaan APBDes dibuat berdasarkan Peraturan Bupati Magetan Nomor 13 Tahun 2017 tentang Laporan Pertanggungjawaban Realisasi Pelaksanaan Anggaran Pendapatan dan Belanja Desa, Peraturan Bupati Sumbawa Nomor 12 Tahun 2015 tentang Pengelolaan Dana Desa, Peraturan Bupati Sumbawa Nomor 47 Tahun 2016 tentang Penyusunan Anggaran Pendapatan dan Belanja Desa Tahun Anggaran 2017.

Dari hasil penelitian yang dilakukan tersebut dapat dirangkum bahwa akuntabiliats pengelolaan APBDes di Desa Poto, Kecamatan Moyo Hilir, Kabupaten Sumbawa sudah berdasarkan pada Peraturan Menteri Dalam Negeri Nomor 113 Tahun 2014.

\section{KESIMPULAN}

Berdasarkan hasil dan pembahasan, penelitian ini meyimpulkan bahwa AKUNABILITAS PENGELOLAAN APBDes Di desa poto dapat di ambil kesimpulannya.

1. Perencanaan program Pengelolaan akuntabilitas APBDes di desa poto telah melaksanaan konsep Perencanaan sekretaris desa menyusun dan menyampaikan rancangan peraturan desa 
tentang APBDes berdasarkan RKPDes kemudian dibahas dan disepakati kepala desa dan bahan permusyawaratan desa

2. Pelaksanaan APBDes desa poto telah di buktikan penerimaan dan pengeluaran dalam rangka pelaksaan melalui rekening kas desa dan pemerintah desa di larang melakukan pungutan sebagai penerimaan desa.

3. Penatausahaan telah di buktikan setiap kegiatan atau program yang sumber dananya dari ABPDes telah di catat dalam buku kas, buku Bank dan buku kas pembantu dan juga di buktikan dengan Transaksi sesuai dengan ketentuan yang berlaku.

4. Pelaporan di desa poto telah di buktikan dalam realisasi keuangan anggaran pendapatan desa pelaporan realisasi APBDes.kepala desa mrmyampaikan laporan realisasi pelaksanaan APBDes kepala bupati/ wali kota setiap semester berjalan.

5. Pertanggungjawaban APBDes dengan cara memberikan laporan pertangggungjawaban kepada masyarakat yaitu dengan menempelkan laporan pengelolaan APBDes dipapan pengumuman pembangunan yang telah disedikan di Balai Desa, selain itu Pemerintah Desa juga menyampaikan Laporan pertanggungjawaban realisasi pengelolaan APBDes kepada Badan Permusyawaratan Desa (BPD), Lembaga Permberdayaan Masyarakat (LPM) pada saat musyawarah penyusunan dan pelaporan APBDes.

\section{SARAN}

Berdasarkan hasil penelitian dan simpulan tentang Akuntabilitas Pemerintah Desa Dalam Pengelolaan APBDesa di Desa poto, maka penulis dapat mengajukan beberapa saran yang terkait dengan penelitian ini.

1. Bagi pemerintah desa

a. Perbaikan secara terus menerus merupakan fokus dari program APBDes dengan selalu mengikuti peraturan perundang undangan terbaru, agar pemerintah desa dapat menglola anggaran.

b. Pembinaan pngelolaan APBDes merupakan sarana efektif untuk keberhasilan program APBDes.

2. Bagi Peneliti Selanjutnya

a. Sebaiknya lebih mengkoordinasikan terlebih dahulu kepada para informan mengenai waktu yang akan digunakan dalam wawancara

b. Untuk menambah informan terutama masyarakat desa dalam pengumpulan data melalui teknik wawancara untuk dapat menilai pertanggungjawaban pemerintah desa dalam pengelolaan APBDes 


\section{DAFTAR PUSTAKA}

Adisasmita, Rahardjo. (2014). Pengelolaan Pendapatan dan Anggaran Daerah. Yogyakarta: Graha Ilmu.

Annisaningrum. (2010). Akuntabilitas dan transparansi dalam laporan keuangan. (Online). 14 Agustus 2017. Http:/ / Ovy 19. Wordpress.Com.

Auditya Lucy, Husaini, Lismawati. (2013). Analisis pengaruh akuntabilitas dan transparansi pengelolaan keuangan daerah terhadap kinerja pemerintah daerah. Jurnal Fairness Volume 3, Nomor 1, 21-41.

Faridah dan Suryono. (2015). "Transparansi dan Akuntabilitas Pemerintah Desa dalam Pengelolaan Anggaran Pendaptan dan Belanja Desa".

Indah, Hanifah Suci. (2015). Akuntabailitas dan Transparansi Pertanggungjawaban Anggaran Belanja Desa (APBDes). Jurnal Ilmu dan

Riset Akuntansi Vol 4, No 8. STIESIA Surabaya.

Iqsan (2016). Transparansi pemerintah desa dalam penyusunan anggaran pendapatan dan belanja desa (APBDes) di Desa Long Nah Kecamatan Muara Ancalong Kabupaten Kutai Timur. e-Journal IlmuPemerintahan,4(1), 230-240.

Ismiarti. (2013). Analisis implementasi sistem pengendalian intern pemerintah,akuntabilitas dan transparansi terhadap kinerja pemerintah. (Tesis.Bengkulu. Program Magister Akuntansi FE UNIB).

Kurniawan, Hendra. (2014). "Akuntbailitas Pengelolaan Alokasi Dana Desa (studi kasus di desa Sukowilangun Kecamatan Kalipare Kabupaten Malang tahun 2014)".

Mahsum Moh, Sulistyowati Firma, Heribertus A.P. (2015). AkuntansiSektorPublik. Yogyakarta: BPFE.

Mardiasmo. (2002). Akuntansi Sektor Publik. Akuntansi Sektor Publik, Yogyakarta: Andi.

Mardiasmo. (2010). Akuntansi Sektor Publik. Yogyakarta: Andi offset.

Moleong, J Lexy. 2000. Metode Penelitian Kualitatif. Bandung: Remaja Rosdakarya.

Nafidah Lina Nasihatun \& Suryaningtyas Mawar. (2015). Akuntabilitas pengelolaan Alokasi Dana Desa alam upaya meningkatkan pembangunan dan pemberdayaan masyarakat. Bisnis, Vol. 3, No. 1.

Nordiawan Deddy, Iswahyudi S.P, Maulidah R. (2007). Akuntansi Pemerintah. Jakarta: Salemba Empat.

Richard, M., dan Musgrave, P., (Eds). (1993). Keuangan negara dalam teori danpraktik. Jakarta: PT Gelora Aksara Pratama. 
Sanusi, A. (2014). Metodologi penelitian bisnis. Jakarta: Salemba Empat.

Sanusi, D.P dan Djumlani, A. (2014). Implementasi kebijakan alokasi dana desa (ADD) di Desa Balansiku Kecamatan Sebatik Kabupaten Nunukan. Volume 2 Nomor 3, 2014.

Soemarso, S.R. (2007). Perpajakan: pendekatan komprehensif. Jakarta: Salemba Empat.

Solekhan, M. (2012). Penyelenggaraan Pemerintah Desa Berbasis PartisipasiMasyarakat dalam Membangun Mekanisme Akuntabilitas. Malang: Setara Press.

Strauss, Anselm dan Juliet Corbin. 1997. Dasar-Dasar Penelitian Kualitatif Prosedur, Tehnik, dan Teori. Surabaya: Bina Ilmu Ofset.

Sugiyono. (2010). Metode penelitian bisnis (Pendekatan kuantitatif, kualitatif, dan r\&d). Bandung: Alfabeta.

Sumpeno, W. (2011). Perencanaan desa terpadu. Banda Aceh: Read

Virgie K.A., Delawillia dan Supranoto. (2013). Implementasi kebijakan pemanfaatan alokasi dana desa. Jurnal Ilmu Administrasi Negara, Volume 12 Nomor 2, Januari 2013 hal 94-103.

Wandari I Desak, Sujana Edy, Putra I Made Pradana Adi. (2015). Pengaruh akuntabilitas, transparansi, ketepatan waktu dan pengawasan internal terhadap kinerja anggaran berkonsep value for money pada instansi pemerintah di Kabupaten Buleleng, Volume 3, No. 1. 